\title{
PENGARUH PROFESIONALISME DAN INDEPENDENSI TERHADAP PENCEGAHAN KECURANGAN DENGAN IKLIM ETIKA-EGOISME SEBAGAI VARIABEL MODERASI
}

\author{
Christine Lie Wijaya ${ }^{1}$, David Adechandra A. P $^{2}$ \\ 1,2 Jurusan Akuntansi, Universitas Kristen Satya Wacana, Indonesia \\ e-mail: christinelieew98@gmail.com¹, david.pesudo@uksw.edu ${ }^{2}$
}

\begin{abstract}
Abstrak
Pencegahan kecurangan diperlukan untuk perusahaan supaya tidak terjadi tindakan kecurangan. Hal ini dipengaruhi oleh sikap profesionalisme dan independensi yang dimiliki oleh auditor internal. Penelitian ini bertujuan untuk menganalisis pengaruh profesionalisme dan independensi terhadap pencegahan kecurangan dengan menggunakan variabel moderasi yaitu iklim etika-egoisme. Data diperoleh dari karyawan di PT. X yang bergerak di bidang farmasi. Sampel yang didapatkan berdasarkan metode saturation sampling yaitu 60 sampel. Hasil penelitian menunjukkan bahwa profesionalisme berpengaruh positif terhadap pencegahan kecurangan, sedangkan independensi berpengaruh negatif terhadap pencegahan kecurangan. Iklim etika-egoisme sebagai variabel moderasi ini memperkuat hubungan antara profesionalisme dan independensi dengan pencegahan kecurangan.
\end{abstract}

Kata kunci : Profesionalisme, Independensi, Kecurangan, Iklim Etika-Egoisme.

\begin{abstract}
Fraud prevention is needed for companies so that fraud does not occur. This is influenced by the attitude of professionalism and independence possessed by internal auditors. This study aims to analyze the effect of professionalism and independence on the prevention of fraud by using a moderating variable that is the ethical climateegoism. Data obtained from employees at PT. $X$ which is engaged in the pharmaceutical field. Samples obtained by the saturation sampling method is 60 samples. The results show that professionalism has a positive effect on fraud prevention, while independence has a negative effect on fraud prevention. Ethical climate-egoism as a moderating variable strengthens the relationship between professionalism and independence with fraud.
\end{abstract}

Keywords : Professionalism, Independende, Fraud, Ethical Climate-Egoism 


\section{PENDAHULUAN}

Kecurangan merupakan salah satu isu dan masalah yang paling menonjol dan menarik perhatian untuk diperbincangkan. Menurut the Association of Certified Fraud Examiners (Association of Certified Fraud Examiners Indonesia Chapter, 2016), kecurangan adalah perbuatan-perbuatan yang dilakukan secara sengaja yang melanggar hukum untuk tujuan tertentu (manipulasi atau memberikan laporan keliru terhadap pihak lain) dilakukan orang-orang dari dalam atau luar organisasi demi keuntungan pribadi ataupun kelompok yang secara langsung atau tidak langsung merugikan pihak lain (Sariguna \& Kennedy, 2017). Banyak berbagai perusahaan telah berkembang di Indonesia, perusahaan yang bergerak di bidang farmasi merupakan salah satu contoh perusahaan yang berkembang di Indonesia. Perusahaan yang bergerak di bidang farmasi ini juga bisa melakukan tindakan kecurangan. Dalam kegiatan operasional perusahaan tentu bisa ditemukan berbagai macam kecurangan yang mungkin saja terjadi. Masalah kecurangan yang sering kita temui adalah korupsi. Namun selain itu juga terdapat masalah yang sering terjadi dalam hal kecurangan yaitu penggelapan gaji karyawan, memanipulasi dokumen dan jumlah angka dalam transaksi, dan dapat kita temui kecurangan yang lain. Hal tersebut dapat dilakukan oleh pihak internal maupun eksternal dari organisasi atau perusahaan tersebut.

Seorang auditor internal harus memiliki sikap profesionalisme dalam menjalankan tugasnya. Hal ini penting karena, dengan profesionalisme tersebut maka auditor dapat menunjukkan sikap dan kinerja yang baik. Selain itu, dengan profesionalisme yang tinggi maka kebebasan seorang auditor juga semakin terjamin. Dalam menjalankan tugasnya, seorang auditor harus memiliki wawasan yang luas mengenai kompleksitas organisasi modern. Profesionalisme merupakan salah satu motivasi seseorang untuk memiliki kinerja yang tinggi (Ramadhaniyati \& Hayati, 2014). Dengan melakukan evaluasi kinerja maka dapat menjadi indikator apakah seorang auditor sudah profesional dalam melaksanakan tugasnya. Apabila sikap profesionalisme ini telah dimiliki oleh seorang auditor maka tindak kecurangan dapat dihindari.

Selain itu, sikap independensi juga harus dimiliki oleh seorang auditor internal. Independensi ini dibutuhkan untuk menjaga kualitas auditor tersebut. Independensi merupakan sikap jujur dari auditor guna mempertimbangkan fakta yang objektif dan menyatakan pendapat (Ramadhaniyati \& Hayati, 2014). Apabila auditor tidak independen, maka akan sulit untuk mendeteksi adanya kecurangan. Maka, seorang auditor internal diharapkan tetap mempertahankan independensi dan profesionalismenya supaya dapat mendeteksi tindak kecurangan yang terjadi pada suatu perusahaan.

Iklim etika dipandang sebagai salah satu komponen budaya organisasi yang dapat mempengaruhi berbagai pengambilan keputusan (Victor \& Cullen, 1988). Salah satu kasus etika yang mungkin dan sering terjadi yaitu masalah mengenai kecurangan. Iklim etika juga berpengaruh kepada auditor internal untuk melakukan kecurangan. Iklim etika memiliki tiga jenis yaitu iklim etika egosime, kebajikan dan prinsip. Dalam pengambilan keputusan seorang auditor internal apabila didasarkan pada iklim etika egoisme maka keputusan tersebut cenderung mengedepankan kepentingan individu. Dengan adanya sikap profesionalisme dan independensi yang tinggi oleh seorang auditor internal tetapi iklim etika-egoisme yang juga tinggi, maka akan berpengaruh pada rendahnya kemungkinan untuk mencegah terjadinya kecurangan.

Kinerja seorang auditor internal tentu berpengaruh terhadap berlangsungnya kegiatan dan mencapai tujuan pada suatu perusahaan (Ramadhaniyati \& Hayati, 2014). Apabila seorang auditor internal memiliki sikap independensi dan profesionalisme yang baik, maka pencegahan kecurangan juga dapat lebih mudah diatasi. Pada penelitian ini, peneliti bermaksud untuk menilai kinerja auditor internal melalui perspektif dari karyawan. Penilaian yang diberikan oleh karyawan diharapkan lebih independen dan tidak bias daripada auditor internal menilai dirinya sendiri.

Profesionalisme dan independensi auditor internal tentu juga diperlukan di perusahaan farmasi untuk mencegah terjadinya kecurangan. Banyak perusahaan farmasi di Indonesia yang memproduksi berbagai macam obat-obatan dengan fungsi yang sama, sehingga hal ini menyebabkan adanya persaingan antar perusahaan farmasi yang ada. Kasus di PT. X yang menentukan harga jual yang terlalu tinggi daripada harga internasional ini mendorong peneliti untuk melakukan penelitian di PT. $X$ yang bergerak di bidang farmasi. Dalam kasus ini juga diketahui adanya transaksional antara dokter dengan produsen obat sehingga terjadi 
anomali harga obat yang berlebihan dan biaya promosi obat untuk dokter yang terlalu tinggi (Widianto, 2010).

Tujuan peneliti melakukan penelitian ini yaitu apakah dengan adanya iklim etikaegoisme dapat memperkuat atau memperlemah profesionalisme dan independensi yang dimiliki auditor internal dalam pencegahan kecurangan. Adapun rumusan masalah dari penelitian ini yaitu (1) apakah profesionalisme mempengaruhi pencegahan kecurangan? (2) apakah independensi mempengaruhi pencegahan kecurangan? (3) apakah iklim etika-egoisme dapat memoderasi pengaruh profesionalisme auditor internal terhadap pencegahan kecurangan? (4) apakah iklim etika-egoisme dapat memoderasi pengaruh independensi auditor internal terhadap pencegahan kecurangan? Sedangkan manfaat dari penelitian ini yaitu agar dapat mendeskripsikan pengaruh iklim etika-egoisme terhadap profesionalisme dan independensi auditor internal guna meningkatkan kinerja auditor internal sehingga dapat melakukan pencegahan terjadinya kecurangan.

Seorang auditor internal memiliki peran yang sangat penting, salah satunya yaitu mencegah terjadinya kecurangan (Asy'ari, Prasetyono, \& Haryadi, 2013). Pencegahan kecurangan merupakan tindakan yang diambil agar kecurangan pada suatu organisasi atau perusahaan tidak terjadi. Tindakan mencegah kecurangan ini tentu tidak mudah dilakukan namun dengan mencegah maka kerugian tidak akan terjadi, dengan begitu bisa dikatakan pencegahan kecurangan merupakan kegiatan memerangi kecurangan dengan biaya yang rendah (Windasari \& Juliarsa, 2016). Dalam menangani kasus kecurangan tentu bukan hal mudah, terlebih lagi kasus-kasus kecurangan seringkali bersifat tersembunyi. Kira-kira terdapat $40 \%$ dari keseluruhan kasus kecurangan yang tidak pernah terungkap, atau sering disebut dengan fenomena gunung es (Windasari \& Juliarsa, 2016). Maka dalam menangani kasus kecurangan diperlukan adanya strategi represif dan preventif.

Dalam pencegahan kecurangan, tentu auditor internal perlu memiliki profesionalisme dan independensi yang tinggi. Profesionalisme seorang auditor internal dapat kita lihat dari kinerjanya sehari-hari, karena profesionalisme merupakan landasan dasar cara berperilaku, berpikir dan bertindak dalam jangka waku yang panjang (Huslina, Islahuddin, \& Syah, 2015). Selain itu, independensi juga merupakan hal yang perlu dipertimbangkan dalam mencegah kecurangan. Seorang auditor internal bisa dikatakan independen apabila tidak mudah terpengaruh oleh pihak manapun.

Profesionalisme merupakan sebuah tanggung jawab pribadi dalam berperilaku untuk menjadi lebih baik dari sekedar mematuhi undang-undang dan peraturan yang ada di masyarakat (Ramadhaniyati \& Hayati, 2014). Salah satu syarat utama yang harus dimiliki oleh seorang auditor internal yaitu sikap profesionalisme. Dengan profesionalisme yang tinggi maka kebebasan seorang auditor akan semakin terjamin. Tingkat profesionalisme seorang auditor internal dapat diukur dengan melakukan evaluasi kerja. Auditor internal yang profesional tentu juga akan memiliki wawasan yang luas mengenai kompleksitas perusahaan (Ramadhaniyati \& Hayati, 2014). Sikap profesionalisme auditor yang tinggi dapat mencegah terjadinya kecurangan yang mungkin saja terjadi, meskipun dalam mendeteksi kecurangan, tidak semua hal mengenai kecurangan dapat diungkapkan oleh seorang auditor internal. Hal yang menjadi alasan seorang auditor tidak dapat selalu megungkapkan kecurangan yaitu misalnya ancaman, mutasi jabatan hingga pemecatan. Apabila seorang auditor internal dapat bersikap profesional, maka terjadinya kecurangan dapat dicegah. Dengan begitu tingkat kepercayaan yang diberikan kepada auditor internal juga semakin meningkat.

Independensi merupakan sikap tidak mudah terpengaruh yang harus dimiliki oleh seorang auditor. Auditor tidak diperbolehkan untuk memihak pada kepentingan siapapun. Apabila seorang auditor menemukan sebuah kecurangan, maka kecurangan tersebut harus tetap dilaporkan meskipun berada dalam tekanan dari suatu pihak (Hartan \& Waluyo, 2016). Meskipun dalam melaksanakan tugasnya, seorang auditor internal berada pada suatu perusahaan tertentu dan menemukan adanya kecurangan maka harus tetap dilaporkan. Namun, apabila seorang auditor internal tersebut menutupi kecurangan yang terjadi bahkan tidak melaporkannya maka auditor tersebut telah kehilangan sikap independen. Yang bisa dikatakan bahwa sikap independen ini merupakan salah satu hal yang sangat penting dimiliki oleh seorang auditor internal dalam mempertahankan kebebasan berpendapat. Independensi sendiri juga merupakan suatu tujuan yang harus selalu diupayakan. Selain itu, independensi juga merupakan kejujuran yang terdapat dalam seorang auditor dalam rangka mempertimbangkan fakta yang objektif dan 
tidak memihak dalam merumuskan dan menyatakan pendapatnya.

Iklim etika-egoisme mengacu kepada tingkah laku yang berkaitan dengan kepentingan individu (Ahmad, 2011). Organisasi atau perusahaan yang mengedepankan iklim etika-egoisme cenderung mementingkan kepentingan pribadi daripada kepentingan bersama dalam pengambilan keputusan. Di iklim etikaegoisme terdapat beberapa hal antara lain perusahaan menuntut karyawan untuk mengambil keputusan yang menguntungkan bagi perusahaan apapun konsekuensinya, kinerja karyawan dapat dikatakan berhasil apabila menguntungkan perusahaan. Selain menguntungkan perusahaan dalam mengambil suatu keputusan, karyawan juga mementingkan keuntungan individu dan keputusan mengenai benar atau salah merupakan keputusan individu dari seorang auditor internal (Floyd, 2010).

Sikap profesionalisme merupakan sikap tanggung jawab yang dimiliki oleh seorang auditor internal. Dengan adanya sikap ini, maka seorang auditor dapat memiliki wawasan yang luas terhadap kompleksitas suatu perusahaan atau organisasi. Profesionalisme berpengaruh terhadap pencegahan kecurangan karena auditor dapat memberikan opini yang objektif, tidak bias dan tidak dibatasi. Maka masalah apa adanya dapat dilaporkan, bukan melaporkan masalah yang sesuai keinginan dari suatu organisasi atau perusahaan tertentu.

Pada penelitian yang dilakukan oleh Yayuk (2012) menyatakan bahwa profesionalisme berpengaruh signifikan dalam mencegah kecurangan. Sama dengan penelitian yang dilakukan oleh Made (2016) bahwa profesionalisme berpengaruh positif pada pencegahan kecurangan. Dalam mencegah terjadinya kecurangan, maka sikap profesional sangat dibutuhkan. Penelitian yang dilakukan oleh Prasetyo (2015) dan Widaningsih \& Hakim (2015) menyatakan bahwa profesionalisme berpengaruh positif pada pendeteksian kecurangan. Apabila kecurangan dapat dideteksi maka dapat mencegah terjadinya kecurangan. Diharapkan dengan memiliki sikap ini maka seorang auditor dapat mendeteksi kecurangan sehingga pencegahan terhadap kecurangan dapat dilakukan. Hasil audit seorang auditor dapat dijadikan indikator apakah seorang auditor tersebut bersikap profesional atau tidak.

Independensi merupakan sikap auditor yang tidak mudah dipengaruhi dan tidak terpengaruh oleh pihak manapun. Dengan adanya sikap independensi yang dimiliki auditor maka dapat mencegah terjadinya kecurangan. Seorang auditor yang independen maka akan mendapatkan kepercayaan dari masyarakat.

Pada penelitian sebelumnya yang dilakukan oleh Yayuk (2012) menyatakan bahwa independensi berpengaruh signifikan dalam mencegah kecurangan. Sama dengan penelitian yang dilakukan oleh Wulandari \& Nuryatno (2018) menyatakan bahwa independensi berpengaruh positif terhadap pencegahan kecurangan. Penelitian yang dilakukan Hartan \& Waluyo (2016) juga menyatakan bahwa independensi berpengaruh positif terhadap mendeteksi kecurangan.

Peneliti menyimpulkan bahwa seorang auditor internal perlu memiliki sikap independen untuk memaksimalkan kinerjanya. Dengan begitu maka seorang auditor dapat bersikap objektif dalam melaporkan kecurangan yang ditemui. Akan sulit apabila seorang auditor internal tidak memiliki sikap independen, hal ini akan menimbulkan akibat yaitu salah satunya kesulitan dalam mencegah terjadinya kecurangan.

Pada perusahaan yang memiliki auditor internal dengan iklim etika-egoisme yang tinggi cenderung memiliki rasa acuh terhadap karyawan yang lain. Hal ini tentu berpengaruh pada profesionalisme dan independensi yang dimiliki oleh auditor internal. Apabila seorang auditor internal memiliki sikap profesionalisme dan independensi yang tinggi namun iklimegoisme di perusahaan juga tingi, maka akan sulit untuk mencegah terjadinya kecurangan. Begitu sebaliknya, apabila iklim etikaegeoisme di perusahaan rendah maka pencegahan kecurangan dapat dilakukan.

Menurut penelitian yang telah dilakukan oleh Distianto (2019) menyatakan bahwa iklim etika yang baik maka tidak mengindikasikan terjadi kecurangan. Sama dengan penelitian yang dilakukan oleh Wilopo (2006) bahwa iklim kerja yang tidak baik berpengaruh terhadap kecenderungan terjadinya kecurangan. Berdasarkan penelitian yang dilakukan oleh Ahmad, Smith, \& Ismail (2013) menyatakan bahwa kondisi organisasional iklim etika dapat mempengaruhi niat whistleblowing di lingkungan Malaysia. Selain itu, penelitian yang dilakukan oleh Rizky (2018) menyatakan bahwa kode etik mendorong seseorang untuk melakukan tindakan whistleblowing. Whistleblowing merupakan salah satu cara untuk melakukan pencegahan kecurangan. 


\section{METODE}

Penelitian ini menggunakan pendekatan kuantitatif karena penelitian ini dilaksanakan guna menguji pengaruh variabel. Dalam penelitian ini menggunakan variabel dependen yaitu pencegahan kecurangan, variabel independen yaitu profesionalisme dan independensi, serta variabel moderasi yaitu iklim etika-egoisme.

Dalam penelitian ini menggunakan jenis data primer yang didapatkan langsung dari responden. Teknik pengambilan data dilakukan dengan membagikan kuisioner menggunakan google forms kepada responden yaitu karyawan di PT. X yang bergerak di bidang farmasi dan merupakan salah satu cabang di kota besar di Indonesia. Populasi yang menjadi objek dari penelitian ini yaitu karyawan di PT. X yang berjumlah 150 karyawan.

Metode sampling yang diguanakan dalam penelitian ini adalah non-probability sampling dengan teknik saturation sampling, yang artinya semua anggota populasi dijadikan sebagai sampel.

Isi dari kuisioner tersebut yaitu tentang penjabaran indikator terkait yang dijabarkan menjadi beberapa pertanyaan atau pernyataan yang diberikan ke responden untuk dijawab dengan menggunakan skala Likert 5 poin. Responden dapat menentukan tingkat persetujuannya dengan memilih salah satu penyataan yang telah disediakan yaitu, 1 (sangat tidak setuju), 2 (tidak setuju). 3 (netral), 4 (setuju), dan 5 (sangat setuju).

Peneliti melakukan uji validitas, uji reliabilitas, dan uji asumsi klasik untuk menguji keabsahan dari penelitian kuantitatif ini. Uji asumsi klasik dengan menggunakan uji normalitas, heterokedastisitas dan multikolineraitas. Peneliti juga menggunakkan dan uji regresi linier berganda dan uji Moderated Regression Analysis (MRA) untuk menguji hipotesis. Uji koefisien determinasi untuk mengukur seberapa jauh kemampuan model dalam menjelaskan variabel dependen.

$$
\begin{aligned}
& \mathrm{Y}=+++ \\
& \mathrm{Y}=++++ \\
& \text { Keterangan: } \\
& =\text { konstanta } \\
& =\text { koefisien } \\
& =\text { profesionalisme } \\
& =\text { independensi } \\
& =\text { iklim etika-egoisme } \\
& =\text { erro. }
\end{aligned}
$$

\section{Pengukuran Variabel}

Tabel 1 Pengukuran Variabel

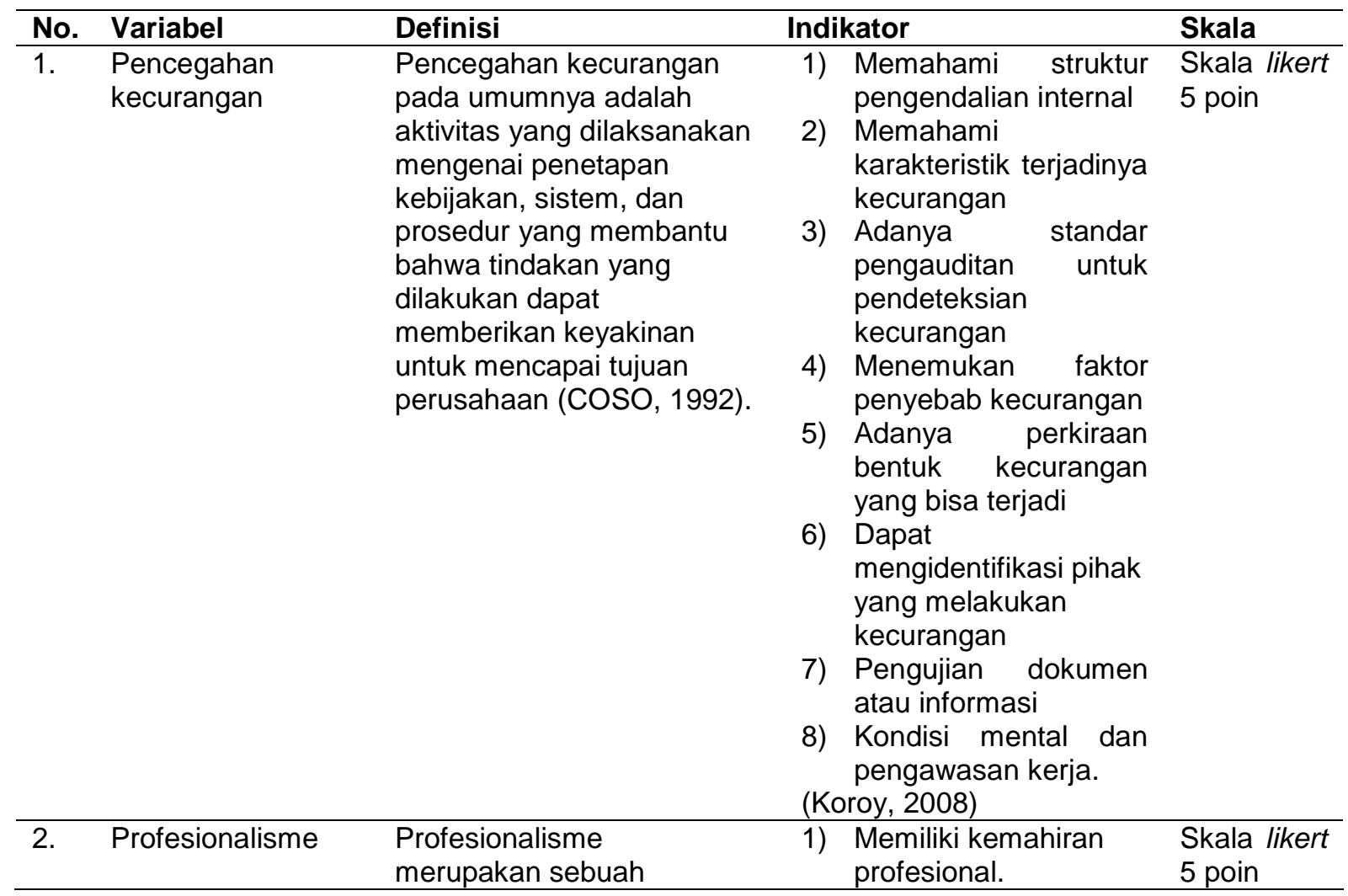




\begin{tabular}{|c|c|c|c|c|}
\hline & $\begin{array}{l}\text { tanggung jawab pribadi } \\
\text { dalam berperilaku untuk } \\
\text { menjadi lebih baik dari } \\
\text { sekedar mematuhi undang- } \\
\text { undang dan peraturan yang } \\
\text { ada di masyarakat } \\
\text { (Ramadhaniyati \& Hayati, } \\
\text { 2014). }\end{array}$ & $\begin{array}{l}\text { 2) } \\
\text { 3) } \\
\text { 4) } \\
\text { (W) }\end{array}$ & $\begin{array}{l}\text { Memiliki independensi } \\
\text { dan kompetensi. } \\
\text { Adanya perencanaan } \\
\text { dan pelaksanaan audit } \\
\text { yang tepat. } \\
\text { Waspada terhadap } \\
\text { bukti audit yang } \\
\text { kontradiksi. } \\
\text { Adanya penaksiran } \\
\text { kritis terhadap } \\
\text { validitas bukti audit. } \\
\text { guna \& Hapsari, 2015) }\end{array}$ & \\
\hline 3. Independensi & $\begin{array}{l}\text { Independensi merupakan } \\
\text { sikap tidak mudah } \\
\text { dipengaruhi oleh pihak lain } \\
\text { (Hartan \& Waluyo, 2016). }\end{array}$ & $\begin{array}{l}\text { 1) } \\
\text { 2) } \\
\text { 3) } \\
\text { 4) } \\
\text { (La }\end{array}$ & $\begin{array}{l}\text { Memiliki rasa ingin } \\
\text { tahu. } \\
\text { Pemikiran mengenai } \\
\text { temuan subjektif. } \\
\text { Lama hubungan } \\
\text { dengan klien. } \\
\text { Tekanan dari klien. } \\
\text { stanti, 2005) }\end{array}$ & $\begin{array}{l}\text { Skala likert } \\
5 \text { poin }\end{array}$ \\
\hline $\begin{array}{l}\text { 4. Iklim Etika- } \\
\text { Egoisme }\end{array}$ & $\begin{array}{l}\text { Iklim etika-egoisme } \\
\text { mengacu kepada tingkah } \\
\text { laku yang berkaitan dengan } \\
\text { kepentingan individu } \\
\text { (Ahmad, 2011). }\end{array}$ & 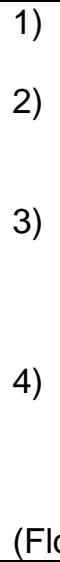 & $\begin{array}{l}\text { Mementingkan } \\
\text { kepentingan pribadi. } \\
\text { Mementingkan } \\
\text { kepentingan } \\
\text { perusahaan. } \\
\text { Pekerjaan dianggap } \\
\text { tidak lancar apabila } \\
\text { merugikan } \\
\text { perusahaan. } \\
\text { Keputusan mengenai } \\
\text { benar atau salah } \\
\text { hanya berdasarkan } \\
\text { keputusan pribadi. } \\
\text { jyd, 2010) }\end{array}$ & $\begin{array}{l}\text { Skala likert } \\
5 \text { poin }\end{array}$ \\
\hline
\end{tabular}

\section{HASIL DAN PEMBAHASAN}

Statistik Deskriptif

Tabel 2 Uji Statistik Deskriptif

\begin{tabular}{llllll}
\hline & $\mathrm{N}$ & Min & Max & Mean & Std. Deviasi \\
\hline Profesionalisme & 60 & 21 & 35 & 30,25 & 3,224 \\
\hline Independensi & 60 & 12 & 25 & 19,75 & 3,597 \\
\hline $\begin{array}{l}\text { Pencegahan } \\
\text { Kecurangan }\end{array}$ & 60 & 24 & 40 & 35,58 & 3,623 \\
\hline $\begin{array}{l}\text { Iklim Etika- } \\
\text { Egosime }\end{array}$ & 60 & 5 & 20 & 11,97 & 3,626 \\
\hline
\end{tabular}

Sumber: data diolah dengan SPSS

Berdasarkan dari Tabel 2, dapat diketahui bahwa sampel yang digunakan dalam penelitian ini yaitu 60 sampel. Karyawan percaya bahwa sikap profesionalisme perlu dimiliki oleh seorang auditor internal, hal ini dibuktikan oleh nilai rata-rata yaitu 30,25. Sikap independensi yang dimiliki oleh seorang auditor internal, yang dibuktikan pada nilai rata-rata yaitu 19,75.

Karyawan percaya bahwa pencegahan kecurangan perlu dilakukan pada suatu perusahaan, hal ini dapat dibuktikan dari nilai rata-rata yaitu 35,58 . Selanjutnya, iklim etika-egoisme dipercaya dapat meningkatkan tindakan kecurangan yang dibuktikan pada nilai rata-rata yaitu 11,97 . 


\section{Uji Validitas dan Realibilitas}

Tabel 3 Uji Validitas dan Reliabilitas

\begin{tabular}{lrcc}
\hline \multicolumn{1}{c}{ Variabel } & Pearson Correlation & Croanbach's Alpha & Keterangan \\
\hline Profesionalisme & 0,704 & 0,817 & Valid dan reliabel \\
PR1 & 0,714 & & \\
PR2 & 0,590 & & \\
PR3 & 0,718 & & \\
PR4 & 0,782 & & \\
PR5 & 0,622 & & \\
PR6 & 0,730 & 0,698 & Valid dan reliabel \\
PR7 & 0,409 & & \\
\hline Independensi & 0,478 & & \\
IN1 & 0,776 & & \\
IN2 & 0,847 & & \\
IN3 & 0,758 & & \\
IN4 & & & \\
IN5 & 0,753 & & \\
\hline Pencegahan Kecurangan & 0,768 & & \\
PK1 & 0,766 & & \\
PK2 & 0,716 & & \\
PK3 & 0,823 & & \\
PK4 & 0,823 & & \\
PK5 & 0,745 & & \\
PK6 & 0,631 & & \\
PK7 & & & \\
PK8 & & & \\
& 0,810 & & \\
\hline Iklim Etika-Egoisme & 0,728 & & \\
IE1 & 0,697 & & \\
IE2 & 0,761 & & \\
IE3 & & & \\
IE4 & & & \\
& & & \\
\hline
\end{tabular}

Hasil dari uji validitas dan reliabilitas menunjukkan bahwa semua variabel sudah valid dan reliabel. Tabel 3 menunjukkan bahwa hasil dari $R$ hitung lebih besar daripada $R$ tabel. Besar $R$ tabel yaitu sebesar 0,2542 dengan tingkat signifikansi 0,05 dan df $(\mathrm{N}-2)$ yaitu 58. Maka dapat dikatakan bahwa seluruh data yang akan diolah sudah lolos uji validitas, karena semua angka yang berada di kolom pearson correlation berada diatas nilai $\mathrm{R}$ tabel. Tabel 3 juga menunjukkan bahwa nilai dari cronbach's alpha lebih dari 0,6 yang berarti dapat disimpulkan bahwa data dari penelitian ini sudah lolos uji reliabilitas.
Sumber: data diolah dengan SPSS

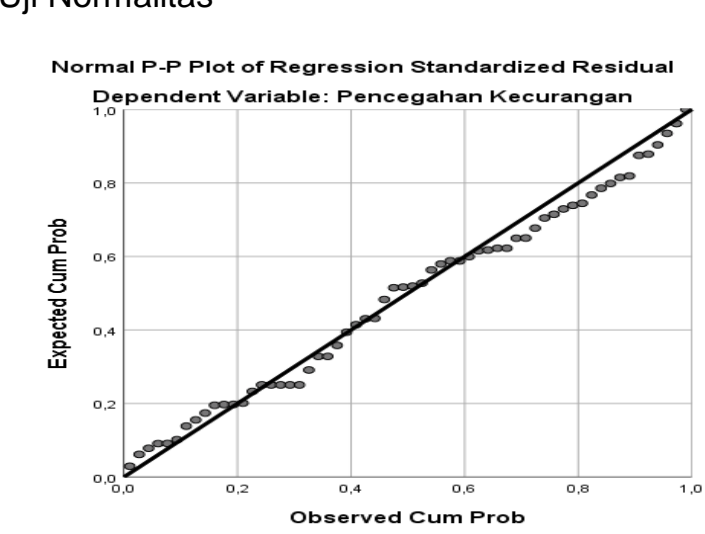

Gambar 1 Uji Normalitas

Berdasarkan dari gambar 1 dapat dilihat bahwa titik-titik mengikuti garis diagonal. Maka dapat disimpulkan bahwa data berdistribusi dengan normal 


\section{Uji Heteroskedastisitas}

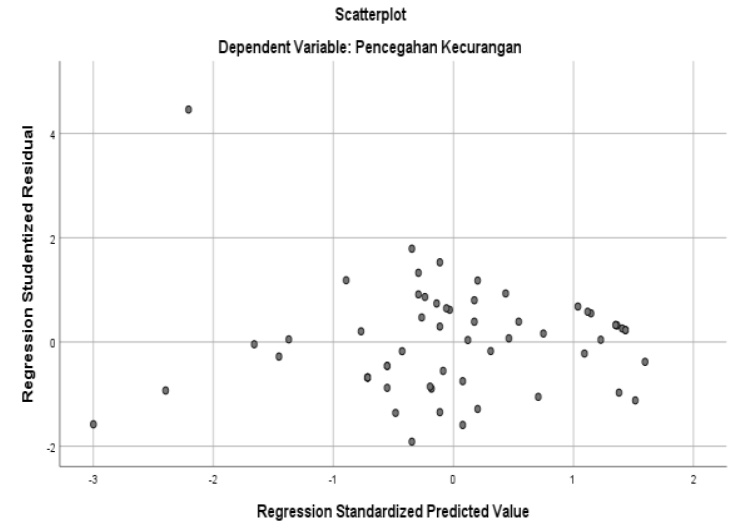

Gambar 2 Uji Heteroskedastisitas
Berdasarkan dari gambar 2 dapat dilihat bahwa titik-titik menyebar di atas dan di bawah angka 0 pada sumbu Y. Maka dapat disimpulkan bahwa tidak ada gejala heteroskedastisitas.

Uji Multikolinieritas

Tabel 4 Uji Multikolinieritas

\begin{tabular}{lcrr} 
& \multirow{2}{*}{ Variabel } & \multicolumn{3}{c}{ Statistik Kolinieritas } \\
\cline { 2 - 4 } & Tolerance & VIF \\
\hline Profesionalisme & 0,961 & 1,041 \\
\hline Independensi & 0,946 & 1,057 \\
\hline Iklim Etika-Egoisme & \multicolumn{2}{c}{0,978} & 1,022 \\
\hline
\end{tabular}

Berdasarkan Tabel 4 di atas dapat dilihat bahwa nilai collinearity tolerance lebih dari 0,100 dan statistics VIF kurang dari 10,00.

\section{Uji Regresi Linier Berganda}

Tabel 5 Uji Regresi Linier Berganda
Maka dapat disimpulkan bahwa tidak terjadi multikolinieritas.

\begin{tabular}{|c|c|c|c|c|c|c|}
\hline Model & & $\begin{array}{c}\text { Undstandardi } \\
\text { zed } \\
\text { B }\end{array}$ & $\begin{array}{l}\text { Coefficients } \\
\text { Std. Error }\end{array}$ & $\begin{array}{l}\text { Standardized } \\
\text { Coefficients } \\
\text { Beta }\end{array}$ & $\mathrm{T}$ & Sig \\
\hline \multirow[t]{3}{*}{1} & (Constant) & 11,334 & 3,248 & & 3,489 & 0,001 \\
\hline & $\begin{array}{c}\text { Profesionalis } \\
\text { me }\end{array}$ & 0,850 & 0,101 & 0,756 & 8,396 & 0,000 \\
\hline & Independensi & $-0,073$ & 0,091 & $-0,073$ & -0.809 & 0,422 \\
\hline
\end{tabular}

Berdasarkan Tabel 5, dapat diketahui bahwa nilai thitung dari profesionalisme yaitu 8,396 lebih besar dari t tabel $(0,025 ; 58)$ yaitu 2,00172 . Nilai signifikansinya yaitu 0,000 lebih kecil dari 0,05, maka profesionalisme berpengaruh positif terhadap pencegahan kecurangan.
Selanjutnya, dapat diketahui bahwa nilai t hitung dari independensi yaitu $-0,809$ lebih kecil dari $t$ tabel $(0,025 ; 58)$ yaitu 2,00172 . Nilai signifikansinya yaitu 0,422 lebih besar dari 0,05 , maka independensi berpengaruh negatif terhadap pencegahan kecurangan 


\section{Uji Moderated Regression Analysis (MRA)}

Tabel 6 Uji MRA

\begin{tabular}{|c|c|c|c|c|c|c|}
\hline Model & & $\begin{array}{c}\text { Undstandardized } \\
\text { B }\end{array}$ & $\begin{array}{l}\text { Coefficients } \\
\text { Std. Error }\end{array}$ & $\begin{array}{c}\text { Standardized } \\
\text { Coefficients } \\
\text { Beta }\end{array}$ & $T$ & Sig \\
\hline 1 & (Constant) & 33,646 & 1,366 & & 24,631 & 0,000 \\
\hline & $\mathrm{X} 1^{*} \mathrm{M}$ & 0,024 & 0,007 & 0,822 & 3,297 & $\overline{0,002}$ \\
\hline & $\bar{X} 2^{*} \mathrm{M}$ & $-0,029$ & 0,010 & $-0,723$ & $-2,900$ & 0,005 \\
\hline
\end{tabular}

Berdasarkan dari Tabel 6, nilai dari signifikansi pada variabel interaksi antara profesionalisme dan iklim etika-egoisme yaitu sebesar 0,002 dan nilai dari signifikansi variabel interaksi antara independensi yaitu sebesar 0,005. Kedua signifikansi tersebut

\section{Koefisien Determinasi}

Tabel 7 Koefisien Determinasi Model 1

\begin{tabular}{llr}
\hline Model & Adjusted R Square & \\
\hline 1 & & 0,540 \\
\hline
\end{tabular}

Sumber: data diolah dengan SPSS

Tabel 8 Koefisien Determinasi Model 2

\begin{tabular}{lrr}
\hline Model & Adjusted $R$ Square & \\
\hline 2 & 0,546 \\
\hline
\end{tabular}

Sumber: data diolah dengan SPSS

Berdasarkan Tabel 7, dapat dilihat bahwa nilai dari Adjusted $R$ square yaitu 0,540 atau $54 \%$. Artinya variabel independen yaitu profesionalisme dan independensi dapat menjelaskan variabel dependen yaitu pencegahan kecurangan. Lau bedasarkan dari tabel 8, nilai dari Adjusted $R$ square variabel interaksi antara profesionalisme dengan iklim etika-egoisme yaitu 0,546 atau $54,6 \%$. Artinya variabel independen (profesionalisme dan independensi) dan variabel moderasi (iklim etika-egoisme) dapat menjelaskan variabel dependen (pencegahan kecurangan).

Dapat disimpulkan bahwa, ada kenaikan sebesar 0,006 didapatkan dari selisih antara 0,546 dengan 0,540, artinya dengan adanya iklim etika-egoisme sebagai variabel moderasi dapat memperkuat pengaruh profesionalisme dan independensi terhadap pencegahan kecurangan.

Hasil dari pengujian ini menunjukkan bahwa pertama, profesionalisme berpengaruh positif terhadap pencegahan kecurangan. Penelitian yang dilakukan oleh Wulandari \& menunjukkan bahwa 0,002 dan 0,005 lebih kecil daripada 0,05, maka iklim etika-egoisme memoderasi hubungan antara profesionalisme dan independensi terhadap pencegahan kecurangan.
Sumber: data diolah dengan SPSS

Nuryatno (2018) menyatakan bahwa profesionalisme berpengaruh positif terhadap pencegahan kecurangan. Sikap profesionalisme yang dimiliki oleh seorang auditor internal dapat mencegah terjadinya suatu kecurangan. Apabila seorang auditor internal memiliki kemahiran profesional serta melakukan perencanaan dan pelaksanaan audit dengan tepat, maka tindakan kecurangan dapat semakin dicegah. Hal ini didukung oleh penelitian yang dilakukan oleh Karamoy \& Wokas (2015) dan Simanjutak (2015) yang menyatakan bahwa profesionalisme berpengaruh positif terhadap pendeteksian kecurangan. Apabilla seorang auditor dapat mendeteksi adanya kecurangan, maka pencegahan kecurangan juga dapat dilakukan.

Kedua, independensi berpengaruh negatif terhadap pencegahan kecurangan. Penelitian yang dilakukan oleh Prasetyo (2015) dan Simanjutak (2015) menyatakan bahwa independensi tidak berpengaruh terhadap pendeteksian kecurangan. Hal ini disebabkan karena seorang auditor tidak 
memiliki rasa ingin tahu, sehingga tindakan kecurangan yang mungkin terjadi tidak dapat dicegah. Potensi kecurangan dapat terjadi akan semakin besar apabila auditor internal tidak berusaha untuk mencari tahu mengenai perusahaan tersebut dimana mungkin saja dapat terjadi kecurangan. Seorang auditor internal yang tidak memiliki sikap independen maka tidak dapat mencegah terjadinya kecurangan. Hal ini sejalan dengan penelitian yang dilakukan oleh Karamoy \& Wokas (2015) yaitu independensi tidak berpengaruh terhadap pendeteksian kecurangan.

Ketiga, iklim etika-egoisme memperkuat hubungan antara profesionalisme dengan pencegahan kecurangan. Keempat, iklim etikaegoisme memperkuat hubungan antara independensi dengan pencegahan kecurangan. Apabila seorang auditor internal memiliki sikap profesionalisme dan independensi dan iklim etika-egoisme sebagai variabel moderasi memperkuat, maka pencegahan kecurangan dapat dilakukan. Hal ini didukung oleh penelitian yang dilakukan oleh Distianto (2019) dan Rizky (2018) dimana iklim etika yang baik maka tidak mengindikasikan terjadinya kecurangan dan kode etik mendorong seseorang untuk melakukan tindakan whistleblowing yang merupakan salah satu cara untuk mencegah terjadinya kecurangan. Iklim etika-egoisme yang rendah pada suatu perusahaan mengakibatkan setiap individu tidak hanya memikirkan kepentingan diri sendiri dan tidak mengambil keputusan demi keuntungan individu. Apabila seorang auditor internal memiliki sikap profesionalisme dan independensi serta iklim etika-egoisme di perusahaan tersebut rendah, maka pencegahan kecurangan dapat dilakukan. Penelitian yang dilakukan oleh Wilopo (2006) yang juga menyatakan bahwa iklim kerja yang tidak baik maka cenderung terjadi kecurangan

\section{PENUTUP}

Berdasarkan dari peneletian yang telah dilakukan, diperoleh berbagai kesimpulan sebagai berikut. Pertama, profesionalisme berpengaruh positif terhadap pencegahan kecurangan. Hal ini berarti semakin tinggi sikap profesionalisme yang dimiliki seorang auditor internal, maka pencegahan kecurangan dapat dilakukan. Kedua, independensi berpengaruh negatif terhadap pencegahan kecurangan. Hal ini disebabkan karena seorang auditor internal kurang memiliki rasa ingin tahu yang tinggi mengenai perusahaan tersebut. Ketiga, iklim etika- egoisme memperkuat hubungan antara profesionalisme terhadap pencegahan kecurangan. Keempat, iklim etika-egoisme memperkuat hubungan antara independensi terhadap pencegahan kecurangan. Hal ini berarti iklim etika-egoisme yang dimiliki oleh perusahaan tersebut rendah maka tindakan kecurangan dapat dicegah.

Keterbatasan dari penelitian ini adalah pengambilan data dilakukan dengan menyebarkan kuisioner melalui link google forms kepada kepala cabang lalu disebarkan ke seluruh karyawan yang menyebabkan peneliti tidak dapat menghimbau kepada karyawan lebih lanjut mengenai pengisian kuisioner. Hal ini menyebabkan sampel yang didapatkan tidak dapat sesuai dengan populasi yang tersedia.

Untuk peneliti yang selanjutnya diharapkan bisa melakukan pengambilan sampel dengan kuisioner secara langsung, sehingga sampel yang didapatkan bisa lebih maksimal. Saran untuk perusahaan yang diteliti yaitu, perusahaan perlu meningkatkan sikap independensi dari seorang auditor internal dan mempertahankan sikap profesionalisme yang sudah ada pada auditor internal

\section{DAFTAR PUSTAKA}

Ahmad, S. A. (2011). Internal Auditors and Internal Whistleblowing Intensions: A Study of Organisasional, Individual, Situational and Demographic Factors. Edith Cowan University, Western Australia.

Ahmad, S. A., Smith, M., \& Ismail, Z. (2013). Internal whistleblowing intentions by internal auditors: a prosocial behaviour perspective. Malaysian Accounting Review, 12(1), 145-182.

Association of Certified Fraud Examiners Indonesia Chapter. (2016). Survai Fraud Indonesia, 1-62.

Asy'ari, M. A., Prasetyono, \& Haryadi, B. (2013). Peran dan Fungsi Satuan Pengawasan Intern Dalam Pencegahan Fraud Pada Perguruan Tinggi X. JAPFA, 01(2), 99-112.

Committee of Spomsoring Organizations of Teadway Commission (COSO). (1992). Internal Control Integrated Framework. 
Distianto, B. O. (2019). Pengaruh Gaya Kepemimpinan melalui Pelembagaan Etika, Iklim Kerja Etis serta Sikap Karyawan terhadap Kecenderungan Kecurangan Akuntansi (Fraud).

Floyd, K. S. (2010). Digital Commons@Georgia_Southern Leadership Styles, Ethics Institutionalization, Ethical Work, Climate, and Employee Attitudes toward Information Technology Misuse in Higher Education: A Correlational Study. Diambil dari

http://digitalcommons.georgiasouthern.ed u/etd.

Hartan, T. H., \& Waluyo, I. (2016). Pengaruh Skeptisme Profesional, Independensi, dan Kompetensi Terhadap Kemampuan Auditor Mendeteksi Kecurangan (Studi Empiris Pada Inspektorat Daerah Istimewa Yogyakarta). Jurnal Profita, (1).

Huslina, H., Islahuddin, \& Syah, N. (2015). Pengaruh Integritas Aparatur, Kompetensi Aparatur, dan Pemanfaaatan Teknologi Informasi Terhadap Efektivitas Sistem Pencegahan Fraud. Jurnal Magister Akuntansi, 4(1), 55-64.

Karamoy, H., \& Wokas, H. R. N. (2015). Pengaruh Independensi dan Profesionalisme, Dalam Mendeteksi Fraud Pada Auditor Internal Provinsi Sulawesi Utara. Jurnal RIset Akuntansi dan Auditing, 6(2).

Koroy, T. R. (2008). Pendeteksian Kecurangan (Fraud) Laporan Keuangan oleh Auditor Eksternal. Jurnal Akuntansi dan Keuangan, 10, 22-33.

Lastanti, H. S. (2005). Tinjauan Terhadap Kompetensi Dan Independensi Akuntan Publik: Refleksi Atas Skandal Keuangan. Media Riset Akuntansi, Auditing, dan Informasi, 5(1), 85-97.

Prasetyo, S. (2015). Pengaruh Red Flags, Skeptisme Profesional Auditor, Kompetensi, Independensi, dan Profesionalisme Terhadap Kemampuan Auditor Dalam Mendeteksi Kecurangan (Studi Empiris Pada Kantor Akuntan Publik di Pekanbaru, Padang, dan Medan yang Terdaftar di IAPI 2013). Jom FEKON, 2(1).
Ramadhaniyati, Y., \& Hayati, N. (2014). Pengaruh Profesionalisme, Motivasi, Integritas, dan Independensi Satuan Pengawasan Internal Dalam Mencegah Kecurangan (Fraud), 02(2), 101-114.

Rizky, D. (2018). Minat Pegawai Untuk Melakukan tindakan Whistle-Blowing System Berdasarkan teori Iklim Etis (Studi Pada Kantor Perwakilan Bank Indonesia Malang). Jurnal IImiah Mahasiswa FEB Universitas Brawijaya, 6(2).

Sariguna, P., \& Kennedy, J. (2017). Para Pelaku Fraud di Indonesia Menurut Survei Fraud Indonesia, 21(September), 50-58.

Simanjutak, S. N. (2015). Pengaruh independensi, Kompetensi, Skeptisme Profesional dan Profesionalisme Terhadap Kemampuan Mendeteksi Kecurangan (Fraud) Pada Auditor di BPK RI Perwakilan Provinsi Sumatera Utara. Jom FEKON, 2(2), 1-13.

Victor, B., \& Cullen, J. B. (1988). The Organizational Bases of Ethical Work Climates. Administrative Science Quarterly, 33, 101-125. https://doi.org/10.2307/2392857

Widaningsih, M., \& Hakim, D. N. (2015). Pengaruh Profesionalisme Auditor Internal Terhadap Pencegahan dan Pendeteksian Kecurangan (Fraud). Jurnal Riset Akuntansi dan Keuangan, 3(1), 586-602.

Widianto, W. (2010). Pfizer dan Dexa Medica Terbukti Lakukan Kartel Obat Hipertensi. Tribun News. Diambil dari https://www.tribunnews.com/nasional/201 0/09/28/pfizer-dan-dexa-medica-terbuktilakukan-kartel-obat-hipertensi

Wiguna, F., \& Hapsari, D. W. (2015). Pengaruh Skeptisme Profesional dan Independensi Auditor Terhadap Pendeteksian Kecurangan (Survei Pada Auditor KAP di Malang). E-proceeding of Management, 2(1), 453-461.

Wilopo. (2006). Analisis Faktor-Faktor yang Berpengaruh Terhadap Kecenderungan Kecurangan Akuntansi: Studi pada Perusahaan Publik dan Badan Usaha Milik Negara di Indonesia. Jurnal 
Nasional, 9(3), 346-366. Diambil dari https://doi.org/10.1001/jama.1994.035201 70077040

Windasari, M. Y., \& Juliarsa, G. (2016). Pengaruh Kompetensi, Independensi, dan Profesionalisme Auditor Internal dalam Mencegah Kecurangan Pada BPR di Kabupaten Badung, 17(3), 1924-1952.
Wulandari, D. N., \& Nuryatno, M. (2018). Pengaruh Pengendalian Internal, Kesadaran Anti-Fraud, Integritas, Independensi, dan Profesionalisme Terhadap Pencegahan Kecurangan. Jurnal Riset Akuntansi Mercu Buana, 4(2), 117-125. 